\title{
The Effect of Air Pollution on Proline and Protein Content and Activity of Nitrate Reductase Enzyme in Laurus nobilis L. Plants
}

\author{
Hamideh Sanaeirad ${ }^{1}$, Ahmad Majd ${ }^{2}$, Hossein Abbaspour $^{1} \&$ Maryam Peyvandi $^{2}$ \\ ${ }^{1}$ Department of Biology, Faculty of Science, Islamic Azad University, Damghan Branch, Damghan, Iran \\ ${ }^{2}$ Department of Biology, Faculty of Science, Islamic Azad University, North Tehran Branch, Tehran, Iran \\ Correspondence: Hamideh Sanaeirad, Department of Biology, Faculty of Science, Islamic Azad University, \\ Damghan Branch, Damghan, Iran. E-mail: h.sanaerad@yahoo.com
}

Received: May 24, 2017

doi:10.5539/jmbr.v7n1p99
Accepted: June 5, 2017

Online Published: June 19, 2017

\begin{abstract}
Nowadays, along with population growth, industrial development and more use of fossil fuel resources; the damages caused by polluted air are being increased across the world. Because of the important role of plants, especially broadleaf plants, in the adsorption of air pollutants, identification of plants resistant to pollution and resistance mechanisms of these plants are essential. In this study, the effect of air pollution on proline and protein content as two metabolites affecting resistance of plants against stresses and especially air pollution, and the activity of the nitrate reductase enzyme as the primer enzyme of biosynthesis pathways of amino acids and synthesis of proteins are investigated in Laurus nobilis L. Plant. The results showed that air pollution in this plant could lead to significant increase in proline and protein and activity of the nitrate reductase enzyme and the increase was significant at the level of $\mathrm{p}<0.01$. Therefore, Laurus nobilis L. Plant as a broadleaf and evergreen plant could be a good choice for polluted cities.
\end{abstract}

Keywords: air pollution, proline, protein, nitrate reductase, Laurus nobilis L.

\section{Introduction}

Air pollution has become tangible since the time that human was centralized as fixed communities and made settlement in different regions and the air pollution was increased gradually over the time and with the establishment of factories. Pollution refers to any kind of change in the features of the environmental components, so that it is impossible to use them as before and they could endanger life and interests of livings things. Undoubtedly, every living thing needs water, foods and air to continue living and air is the most important factor in this field. In the urban areas, trees play a vital role in the improvement of air quality through adsorption of gases and particles in the air (Woo \& Je, 2006). Leafs of plants could be a broad surface for contact, adsorption and contamination of air pollutants and reduction of air pollution in the air; although this level varies in different plants. They act as adsorbents for lots of particles in the air (Joshi \& Swami, 2009).

Laurus nobilis L. from Lauraceae family, is an aromatic evergreen tree or large shrub (Fig 1,2) with green, glossy leaves, native to the Mediterranean region. It is a medicamental plant and one of the plants used for bay leaf seasoning in cooking. Under favorable conditions, its height reaches even to $15-20 \mathrm{~m}$; although it is usually $7-8 \mathrm{~m}$ in height. It is a polygamy plant and male and female flowers and also hermaphrodite flowers may be observed on a tree. The leaves are alternate, dark green, oval, sharp and fragrant and beautiful (Panza et al., 2011). Broadleaf plants could take photosynthesis action better than others because of the width of the surface of their leaves. Hence, they could be more effective than conifers in the field of air cleaning. However, it should be noted that when the temperature inversion phenomenon and air pollution occurs in polluted cities like Tehran, broadleaf plants have been decayed and play no role in the reduction of air pollution (Department of Environment). Therefore, analysis of plant like Laurus nobilis L as a pharmaceutical, broadleaf and evergreen plant is vital. 


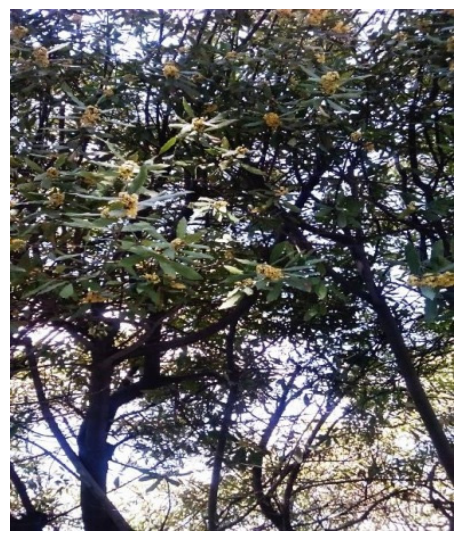

Figure 1. Tree of Laurus nobilis L.

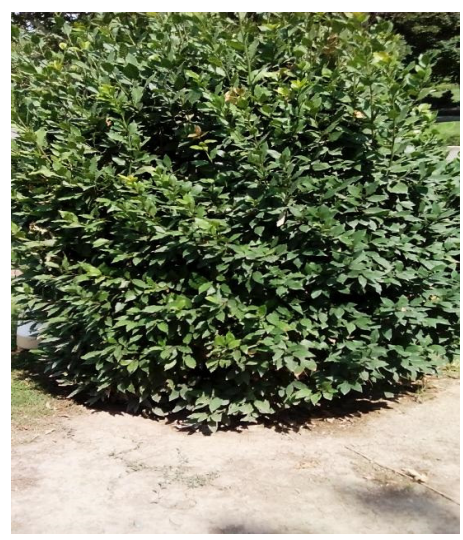

Figure 2. shrub of Laurus nobilis L.

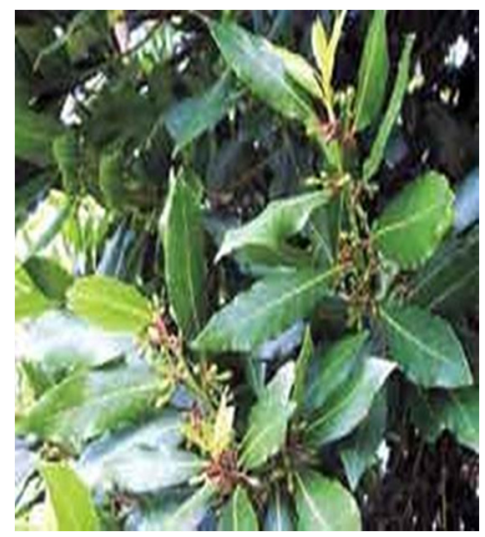

Figure 3. leaves of Laurus nobilis L.

Tehran with area about $12981 \mathrm{~km}^{2}$ is located between 34 and 36.5 degrees north latitude and 50 to 53 degrees east longitude. Tehran ends in the southern slopes of the Alborz from the north and ends at the northern edge of the central desert of Iran from south. The slope of the province is north-south and its average height is to $1200 \mathrm{~m}$ above sea level. In different areas of the province, because of special geographical location, different climate has been formed. Jamshidieh Park (district 1) is located on Alborz Slopes. This park is adjacent to Kalkachal Mountains. This park, with an area about $10 \mathrm{ha}$ is located at the beginning of the main road of climbing to kalkachal Shelter and in the neighborhood of Ferdowsi Park and its height above sea level is equal to 1820 to $2100 \mathrm{~m}$. Be'sat Park is located in south of Tehran (district 16) and in adjacency of Terminal Jonub with an area about 53ha and height of 1000 above sea level (Parks and Green Spaces Organization of Tehran).

\section{Materials and Methods}

\subsection{Site Selection}

Tehran, a capital city of Iran, is located in large valley-like vicinity surrounded by mountains from three sides. The natural air ventilation of Tehran is further inhibited due to the location of the city at 30-degree north altitude and presence of downward waves. The city has a very low level of rain and the annual thermal inversion in Tehran is expected to be approximately 240 days (Forohar, 1991). A large number of industrial settings and stationary sources of air pollutants are located in the south and south-west of Tehran. The wind streams that normally occur from west to east may transport airborne contaminants into the city where it is already polluted by a huge number of motor vehicle emissions and mobile sources of contamination. Therefore, considering the information obtained from the Tehran Environmental Protection Agency and the Air quality Control Office, Jamshidieh Park (1 area) and Besat Park (16 area) were selected as two sampling sites representing the unpolluted and polluted area respectively.

\subsection{Air Quality Analysis}

During the exposure period, ambient air quality in terms of common air pollutants was analysed at two bioindicator stations (Table 1).

\subsection{Sample Collection}

In this study, the air pollution effects on the activity of antioxidant enzymes were investigated in Laurus nobilis plant clones (Fig. 1, 2). The leave samples of plants (the 5th leave of middle branches) were collected from both sampling sites simultaneously. The average of four samples was collected for each plant and collected samples were transferred to the laboratory at cold temperature $\left(4^{\circ} \mathrm{C}\right)$.

\subsection{Measurement of Proteins (Bradford, 1979)}

For extracting the proteins, fresh leaves $(1 \mathrm{~g})$ were homogenized in Tris- $\mathrm{HCl}$ buffer $(5 \mathrm{~mL} ; 0.05 \mathrm{M} ; \mathrm{pH}=7.5)$. The homogenized samples were then filtered and centrifuged at $13000 \mathrm{~g}$ for $20 \mathrm{~min}$ at $4^{\circ} \mathrm{C}$. The samples of supernatant were kept at $4^{\circ} \mathrm{C}$ before protein analysis. Using Tris-glycine buffer solution and Bradford reagent in spectrophotometer was regulated on 0 in wavelength of $595 \mathrm{~nm}$ and adsorption of samples was recorded by the device. In all mentioned steps, the tube container, containing test tubes, was in a dish of ice. Finally, concentration of unknown proteins was obtained based on the standard curve. 
Measurement of proline content (Bates et al., 1973): $0.5 \mathrm{gr}$ of fresh aerial material was sandblasted properly in porcelain dish and was homogenized after weighting with $10 \mathrm{ml} 3 \%$ Sulfosalicylic acid. Then, the extract of all samples was transferred to centrifuge tubes and they were centrifuged in $4000 \mathrm{~g}$ for $20 \mathrm{~min}$. the surface solution was isolated from the deposited part and $2 \mathrm{ml}$ of the solution was poured in test tubes and in the next step, $2 \mathrm{ml}$ acid hydrine and $2 \mathrm{ml}$ pure acid acetic were added to all tubes. Then, all the tubes were placed in bath with temperature of $100^{\circ} \mathrm{C}$ for 1 hour. Afterwards, the temperature of the tubes was recorded after removing them from the bath and they were fixed in a dish of ice. In the next step, $4 \mathrm{ml}$ toluene was added to each tube and was mixed for $15-20 \mathrm{~s}$ intensely. After fixation of tubes, two separate layers were created and the proline-containing toluene (upper colorful section) was isolated from the blue layer (lower section) and was placed on the upper layer of the solution. Then, the colorful part was isolated and the surface adsorption of all samples along wavelength of $520 \mathrm{~nm}$ was read against the device witness (toluene) using a spectrophotometer. After that, the standard curve was drawn and according to the curve, the proline content in unknown samples was estimated based on micromoles per gram of fresh weight.

Measurement of the activity of the nitrate reductase enzyme (Sym, 1984): $0.5 \mathrm{gr}$ of wet tissue of the sample was sandblasted with $5 \mathrm{ml}$ of incubation solution containing $1 \mathrm{ml}$ nitrate potassium of $150 \mathrm{MM}, 1 \mathrm{ml} 3 \%$ propanol and $3 \mathrm{ml}$ tampon phosphate of $100 \mathrm{MM}$. Then, the test tube was placed in an oven under the temperature of $30^{\circ} \mathrm{C}$ for 1 hour and was then filtered. $2 \mathrm{ml}$ of solution was taken and respectively $1 \mathrm{ml}$ of grease I solution and $1 \mathrm{ml}$ Grease II solution were added and their adsorption was read in $520 \mathrm{~nm}$. Grease I solution: $0.5 \mathrm{gr}$ of acid sulfanilic acid was solved in $50 \mathrm{ml}$ acid acetic and its volume was reached to $100 \mathrm{ml}$; grease II solution: $0.2 \mathrm{gr}$ of Alpha-naphthyl A was solved in $50 \mathrm{ml}$ acid acetic and its volume reached to $100 \mathrm{ml}$. the activity of nitrate reductase could be found from the amount of nitrate produced per hour per gr of wet material (A) as follows:

$$
A=\frac{C \times 0 / 005}{W}\left(\mu M N o_{2}^{-} g^{-1} \cdot h^{-1}\right)
$$

Where; $\mathrm{C}=$ the read adsorbed content, $\mathrm{W}=$ wet sample weight.

\subsection{Statistical Analysis}

Statistical analyses were performed using Microsoft Excel 2002 and SPSS (version 12.0) Software. Experimental results were expressed as the mean \pm standard deviation $(\mathrm{m} \pm \mathrm{SD})$ of four different replicates. One way analysis of variance (ANOVA) was used to compare the average enzyme levels of different sample groups, followed by multiple comparisons and Duncan tests to identify which group was statistically significantly different. Differences were considered statistically significant at $p<0.01$.

\section{Results}

The results of Air quality analysis showed (Table 1).

Table 1. Ambient air quality for different bioindicator stations

\begin{tabular}{cccccccc}
\hline $\begin{array}{c}\mathrm{PM}_{2.5} \\
\mu \mathrm{g} / \mathrm{m}^{3}\end{array}$ & $\begin{array}{c}\mathrm{PM}_{10} \\
\mu \mathrm{g} / \mathrm{m}^{3}\end{array}$ & $\begin{array}{c}\mathrm{So}_{2} \\
\mathrm{ppb}\end{array}$ & $\begin{array}{c}\mathrm{No}_{2} \\
\mathrm{ppb}\end{array}$ & $\begin{array}{c}\mathrm{O}_{3} \\
\mathrm{ppb}\end{array}$ & $\begin{array}{c}\mathrm{Co} \\
\mathrm{ppm}\end{array}$ & DATE & STATION \\
\hline 14 & 37 & 11 & 36 & 10 & $1 / 4$ & $2015 / 6$ & 1 area \\
13 & 26 & 16 & 47 & 12 & $1 / 6$ & $2015 / 7$ & 1 area \\
16 & 42 & 20 & 44 & 14 & $1 / 5$ & $2015 / 8$ & 1 area \\
18 & 44 & 10 & 28 & 15 & $1 / 7$ & $2014 / 6$ & 1 area \\
17 & 43 & 18 & 27 & 13 & $1 / 1$ & $2014 / 7$ & 1 area \\
12 & 37 & 21 & 19 & 12 & $1 / 4$ & $2014 / 8$ & 1 area \\
76 & 141 & 28 & 73 & 38 & $4 / 7$ & $2015 / 6$ & 16 area \\
73 & 119 & 34 & 81 & 41 & $3 / 9$ & $2015 / 7$ & 16 area \\
82 & 136 & 32 & 78 & 35 & $3 / 7$ & $2015 / 8$ & 16 area \\
69 & 114 & 29 & 70 & 35 & $4 / 1$ & $2014 / 6$ & 16 area \\
74 & 135 & 36 & 85 & 33 & $4 / 5$ & $2014 / 7$ & 16 area \\
71 & 123 & 33 & 77 & 43 & $4 / 6$ & $2014 / 8$ & 16 area \\
\hline
\end{tabular}

The results associated with total protein content: total protein content in samples of pollutant area was more than other areas and this value was significant at the level of $1 \%(p<0.01)$ (figure 4$)$. The lowest protein content was to 
$0.5688 \mathrm{mg} / \mathrm{g}$ of wet weight and was related to Jamshidieh Park (clean zone) and the highest protein content was to $1.7146 \mathrm{mg} / \mathrm{g}$ of wet weight and was related to sample of Be'sat Park (polluted zone).

The results associated with proline content: the proline content in the samples of polluted area was more than other areas and this value was significant at the level of $1 \%(\mathrm{p}<0.01)$ (figure 5). The lowest proline content to 25.2068MM/g wet weight was related to sample of Jamshidieh Park (clean zone) and the highest content of proline to $99.9023 \mathrm{MM} / \mathrm{g}$ of wet weight was related to sample of Be'sat Park (polluted zone).

Results associated with nitrate reductase enzyme: the activity of the nitrate reductase enzyme (NR) was high in samples of polluted zone and this value was significant at the level of $1 \%(\mathrm{p}<0.01)$ (figure 6$)$. The lowest activity rate of NR enzyme based on the nitrate content produced per hour per gr of wet matter was equal to 2.643 and was related to sample of Jamshidieh Park (clean zone) and the highest activity rate of NR enzyme based on the nitrate content produced per hour per gr of wet matter was equal to 8.8259 and was related to sample of Be'sat Park (polluted zone).

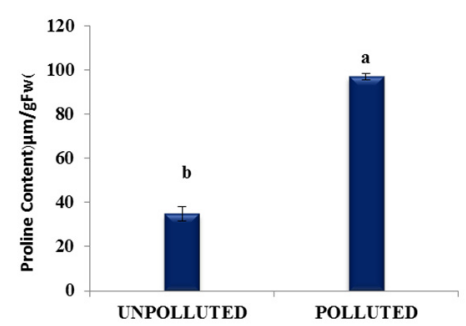

Figure 4. The variation of Proline content

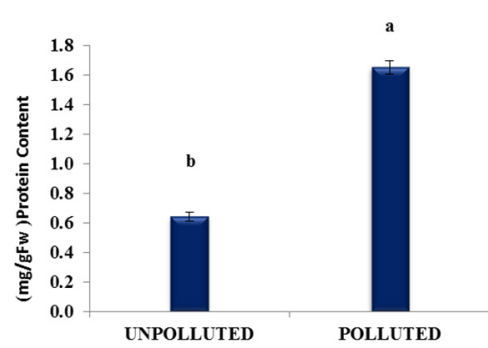

Figure 5. The variation of Protein content

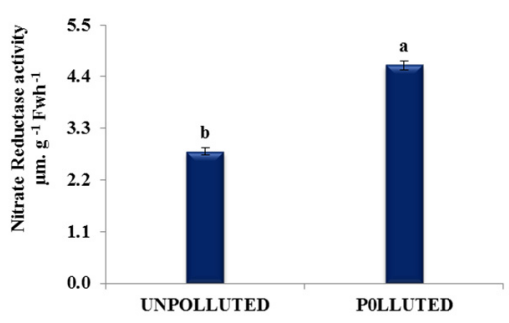

Figure 6 . The variation of NR enzyme activity

\section{Discussion}

Air pollution can directly affect plants. When exposed to airborne pollutants, most plants experienced physiological changes before exhibiting visible damage to leaves (Liu \& Ding, 2008). The use of vegetation samples as bioindicators of the degree of pollution through biochemical study in environmental monitoring is well known (Abed Esfahani et al., 2014).

In this study, increased activity of NR enzyme was in line with an increase in protein content. This result was in consistence with findings of Singh et al. (1985) and Furlan et al. (2004) and was not in consistence with findings of Tripathi and Gautam (2007). Nitrate reductase is an enzyme that is responsible for catalyzing nitrate to nitrite and this could be the regulating step of the pathway of $\mathrm{NO}_{3} \rightarrow \mathrm{NO}_{2} \rightarrow \mathrm{NH}_{4} \rightarrow$ amino acids in the synthesis of amino acids. The source of nitrate may be NOx pollutants in the atmosphere. Atmospheric nitrogen oxides may show a reaction with extracellular water of leaves for the formation of nitrate and nitrite and be homogenized finally with nitrogen metabolism. Moreover, some other pollutants such as SO2 and O3 have been specified to create higher levels of leaf nitrogen (Furlan et al., 2004). The results related to protein were in consistence with findings of Singh et al. (1985) and have been inconsistent with findings of Seyyednejad et al. (2013). In plants, nitrate is converted to nitrite by the NR enzyme and the nitrite is also immediately converted to ammonium by NR enzyme and could enter to the pathway of production of amino acids. In plants, NR enzyme plays a key role in the processes related to nitrate intake. Various evidences have shown the complexity of regulation of these enzymes (Campbell, 1999; Huber \& Huber, 1995; Werner et al., 1995). Defect in activity of this enzyme or factors affecting relevant cycles of this enzyme could lead to contamination of nitrate in different organs of plants (Campbell, 1999). Azote is one of the most important elements in nutrition of plants (Neyra \& Hangeman, 1975). When the azote content and its type is appropriate in nutrition of plant, formation of protein materials is increased, the livability of the plant is enhanced, leaf growth is accelerated and their ageing process is slowed down (Tatsumi, 1982) (Yamashita et al., 1994). In soil, azote is provided for roots of organic plants as nitrate and ammonium; although nitrate is the main source of azote (Baligar \& Schanffert, 1993). Intake of ammonium and nitrate is changed under the effect of concentration of carbonic gas, so that increase in concentration of carbonic gas in the environment could increase nitrate intake in roots; although it has not effect on intake of ammoniac. Moreover, increased intake of nitrate, along with increased concentration of carbonic gas could increase the concentration of carbohydrates in the root (Fentem et al., 1983). Nitrate takes the recovery and fixation in leaf and the major part of the activity of NR enzyme 
is in aerial part and nitrate is recovered mainly on leaves (Lewis et al., 1990). Increased ammoniac content in the environment could cause stress because of its toxicity and the total protein content of plants is increased to overcome it and some of them could be considered as an urgent reactor agent (Singh et al., 1985). There is a positive correlation across the protein and proline and one condition of ammoniac increased stress is detoxification with accumulation of polyamines and proline (Singh et al., 1985). Proline contamination could mostly happen in different varieties of plants under different stresses. For example, it is reported in leaves of plants exposed to $\mathrm{SO} 2$ (Tankha \& Gupta, 1992), heavy metals (Wang et al., 2009) and salt (Woodward \& Bennett, 2005). It seems that there is a correlation between lipid peroxidation and proline contamination in plants in contact with different types of stress (Wang et al., 2009). If such correlation is existed, it could be mentioned that proline contamination could play key role in preventing lipid peroxidation stimulated by air pollution. Proline contamination occurs mostly in different plants exposed to different types of stress. For example, proline contamination is reported in plants in contact with SO2 vapor (Tankha \& Gupta, 1992), heavy metals (Wang et al., 2009) and salt (Gupta, 1992; Wang et al., 2009; Woodward \& Bamett, 2005). Moreover, this study has shown that the proline content of polluted leaves was increased in reaction to air pollution conditions significantly. High contact with air pollutants could make chloroplast stimulate an energy level, which could typically lead to increase in ROS production and creation of oxidative stress (Woo et al., 2007). Harmful effects of pollutants are caused by production of types of activated oxygen (ROS) in plants and could lead to destruction of cell components (Tiwari et al., 2013). Proline acts as an absorbent and free radical to protect plants against oxidative stress. Although the adsorption reaction of ROS is done by other amino acids like tryptophan, tyrosine, histidine and other ones, proline are underlying because of its high concentration in plants while environmental stresses (Wang et al., 2009). Proline contamination could reduce damage of membrane and proteins. In addition to osmosis regulation, proline is responsible for regulating cell $\mathrm{pH}$, oxidation and recovery, carbon resource and nitrogen. Some scholars have presented some reports on increased proline content in reaction to different environmental stresses in plants (Levitt, 1972). Environmental stresses include high and low temperature, drought, air and soil pollution, which could increase activated oxygen (ROS) in plant cells as toxic and reactant elements (Pukacka and Pukacki, 2000). Being exposed to air pollutants could make a rise of chloroplast to high stimulation level and this could lead to increase in ROS production and as a result, oxidative stress (Woo et al., 2007). Harmful effects of ROS caused by air pollutions could lead to cell destruction in plants (Tiwari et al., 2013). It has been reported that proline acts as a free radical absorbent to protect plants against oxidative stress damages (Wang et al., 2009). Proline is a general accumulated Osmolytes in response to stresses and plays a role in defensive reactions of plants (Khattab, 2007). Clearly, proline plays key role in the protection of plants against types of stresses and contamination of proline in plants is a physiological reaction to osmotic stress (Szekely, 2004). The impact of pollution on plants includes destruction of pigments, reduction of cell lipid and peroxidation of unsaturated fatty acid (Tiwari et al., 2013). It seems that there is a correlation across lipid peroxidation and contamination of proline in plants under the different stresses (Wang et al., 2009). If such correlation has existed, accumulation of proline plays probably an important role in controlling lipid peroxidation caused by polluted air (Seyyednejad et al., 2013). In regard with an increase in proline content on different cell performances, various theories are presented. For example, proline preserves the water intake capacity in cell cytoplasm and leads to protection of macromolecules such as enzymes, to prevent formation of undesirable forms or their fragmentation (Wang et al., 2009).

In summary, many changes in plant physiology and growth, such as those caused by air pollution, are biological compensatory responses to environmental stress. The main stress compensatory strategy in plants is to minimize damage from stress (Woo et al., 2007). In fact, these changes help plants minimize stress and maximize use of internal and external resources (Dineva, 2004).

\section{References}

Baligar, V. C., Schaffert, R. E., Dos Santos, H. L., Pitta, G. V. E., \& Bahia Filho, D. C. (1993). Growth and nutrient uptake parameters in sorghum as influenced by aluminum. Agronomy Journal, 85(5), 1068-1074.

Bates, L. S., Waldren, R. P., \& Teare, I. D. (1973). Rapid determination of free proline for water-stress studies. Plant and soil, 39(1), 205-207.

Bradford, M. M. (1976). A rapid and sensitive method for the quantitation of microgram quantities of protein utilizing the principle of protein-dye binding. Analytical biochemistry, 72(1-2), 248-254.

Campbell, W. H. (1999). Nitrate reductase structure, function and regulation: bridging the gap between biochemistry and physiology. Annual review of plant biology, 50(1), 277-303.

Dineva, S. B. (2004). Comparative studies of the leaf morphology and structure of white ash Fraxinus americana L. and London plane tree Platanus acerifolia Willd growing in polluted area. Dendrobiology, 52, 3-8. 
Esfahani, A. A., Amini, H., Samadi, N., Kar, S., Hoodaji, M., Shirvani, M., \& Porsakhi, K. (2013). Assesment of Air Pollution Tolerance Index of Higher Plants Suitable for Green Belt Development in East of Esfahan City, Iran. Journal of Ornamental and Horticultural Plants, 3(2), 87-94.

Fentem, P .A., Lea, P .J., \& Strwart, C .R. (1983).Ammonium assimilation in the roots of nitrate andammonium grown Itordume Vulga (C.V.Goldenpromis). Plant Physiol, 77, 496-501.

Forohar, F. (1991). Air pollution of Tehran and the ways of prevention. Tehran. Iran.

Furlan, C. M., Salatino, A., \& Domingos, M. (2004). Influence of air pollution on leaf chemistry, herbivore feeding and gall frequency on Tibouchina pulchra leaves in Cubatão (Brazil). Biochemical systematics and ecology, 32(3), 253-263.

Huber, S. C., \& Huber, J. L. (1995). Metabolic activity of spinach leaf nitrate reductase. Effects on enzymaticactivity and de-phosphorylation endogenous phosphatase. Planta, 196, 180-189.

Joshi P. C., \& Swami, A. (2009). Air pollution induced changes in the photosynthetic pigments of selected plant species. J. Environ. Boil, 30, 295-298.

Kaiser, W. M., \& Brendle-Behnisch, E. (1995). Acid-base-modulation of nitrate reductase in leaf tissues. Planta, 196(1), 1-6.

Khattab, H. (2007). The deffence mechanism of cabbage plant against phloem- stucking aphid (Brevicoryne brassicae L.). Aust. J. Basic Applied Sci, 1, 56-62.

Levitt, J. (1972). Respons of plant to environmental stresses. Environmental Pollution, 17, 111-115.

Lewis, O. A. M., Cramer, M., \& Van Der Leij, T. (1990). Influence of nitrogen source on carbon distribution in plants exhibiting the $\mathrm{C} 3$ and $\mathrm{C} 4$ photosynthetic pathways. In Inorganic Nitrogen in Plants and Microorganisms (pp. 329-335). Springer Berlin Heidelberg.

Liu, Y. J., \& Ding, H. (2008). Variation in air pollution tolerance index of plants near a steel factory: Implication for landscape-plant species selection for industrial areas. WSEAS Transactions on Environment and development, 4(1), 24-32.

Neyra, C. A., \& Hageman, R. H. (1975). Nitrate uptake and induction of nitrate reductase in excised corn roots. Plant Physiology, 56(5), 692-695.

Panza, E., Tersigni, M., Iorizzi, M., Zollo, F., De Marino, S., Festa, C., ... \& Ianaro, A. (2010). Lauroside B, a megastigmane glycoside from Laurus nobilis (bay laurel) leaves, induces apoptosis in human melanoma cell lines by inhibiting NF-кB activation. Journal of natural products, 74(2), 228-233.

Pukacka, S., \& Pukacki, P. M. (2000). Seasonal changes in antioxidant level of Scots pine (Pinus sylvestris L.) needles exposed to industrial pollution. I. Ascorbate and thiol content. Acta Physiologiae Plantarum, 22(4), 451-456.

Seyyednejad, S. M., Koochak, H., \& Vaezi, J. (2013). Changes in antioxidative enzymes activity, protein content and ascorbic acid level in Prosopis juliflora exposed to industrial air pollution. Journal of Biology and Today's World, 10, 482-492.

Singh, N. K., Handa, A. K., Hasegawa, P. M., \& Bressan, R. A. (1985). Proteins associated with adaptation of cultured tobacco cells to NaCl. Plant Physiology, 79(1), 126-137.

Sym, G. J. (1984). Optimisation of the in-vivo assay conditions for nitrate reductase in barley (Hordeum vulgare L. cv. Igri). Journal of the Science of Food and Agriculture, 35(7), 725-730.

Szekely, G. (2004). The role of proline in Arabidopsis thaliana osmotic stress. Acta Biologica Szegediensis, $48(1-4), 81$.

Tankha, K., \& Gupta, R. K. (1992). Effect of water deficit and sulphur dioxide on total soluble proteins, nitrate reductase activity and free proline content in sunflower leaves. Biologia plantarum, 34(3), 305-310.

Tatsumi, J. (1982). Growth of crops and transport nitrogen. Growth of crop roots and transport of nitrogen agricul. Hortical, 57, $637-638$.

Tiwari, S. H. (2013). Air pollution induced changes in foliar morphology of two shrub species at Indore city, India. Research Journal of Recent Sciences, 2, 195-199.

Tripathi, A. K., \& Gautam, M. (2007). Biochemical parameters of plants as indicators of air pollution. Journal of Environmental Biology, 28(1), 127. 
Wang, F., Zeng, B., Sun, Z., \& Zhu, C. (2009). Relationship between proline and Hg2+-induced oxidative stress in a tolerant rice mutant. Archives of environmental contamination and toxicology, 56(4), 723.

Woo, S. Y., \& Je, S. M. (2006). Photosynthetic rates and antioxidant enzyme activity ofPlatanus occidentalis growing under two levels of air pollution along the streets of Seoul. Journal of Plant Biology, 49(4), 315319.

Woo, S. Y., Lee, D. K., \& Lee, Y. K. (2007). Net photosynthetic rate, ascorbate peroxidase and glutathione reductase activities of Erythrina orientalis in polluted and non-polluted areas. Photosynthetica, 45(2), 293295.

Woodward, A. J., \& Bennett, I. J. (2005). The effect of salt stress and abscisic acid on proline production, chlorophyll content and growth of in vitro propagated shoots of Eucalyptus camaldulensis. Plant Cell, Tissue and organ culture, 82(2), 189-200.

Yamashita, K., Kasai, M., Yamamoto, Y., \& Matsumoto, H. (1994). Stimulation of plasma membrane h+transport activity in barley roots by salt stress. Soil science and plant nutrition, 40(4), 555-563.

\section{Copyrights}

Copyright for this article is retained by the author(s), with first publication rights granted to the journal.

This is an open-access article distributed under the terms and conditions of the Creative Commons Attribution license (http://creativecommons.org/licenses/by/4.0/). 